\title{
The Great Cat and Dog Massacre: the Real Story of World War II's Unknown Tragedy
}

Review Number: 2184

Publish date: Thursday, 26 October, 2017

Author: Hilda Kean

ISBN: 9780226318325

Date of Publication: 2017

Price: $£ 19.95$

Pages: 248pp.

Publisher: University of Chicago Press

Publisher url: http://press.uchicago.edu/ucp/books/book/chicago/G/bo22091014.html

Place of Publication: Chicago

Reviewer: Maggie Andrews

There is selectivity in many of the narratives of how animals' lives have been shaped by warfare in the 20th century, which often focuses on their bravery and loyalty as they are used and abused on battlefields. Thus in the popular imagination the brutality of the First World War Western Front is now entwined with the experiences of one horse, Joey, who went from farm to fighting- fields and was the focus of Michael Morpogo's Warhorse (1982). Few people however are aware of events around which The Great Cat and Dog Massacre is pivoted, the destruction of 400,000 cats and dogs in the four days of September 1939 as the Second World War began. This book explores both the attitudes and practices that led up to this massacre and the animal and human relationships that developed in its aftermath.

The Second World War Home Front has been the subject of a range of academic work. Since Calder's seminal work The People's War (1969) interrogated the lived experience of everyday life during the conflict. Both he and a number of other writers have challenged the tenacious and inaccurate myth that this was a conflict in which stoical Britains all pulled together, in equality of sacrifice with grim determination and good humour. Within this field of history it is rare that for book to come along which offers a completely new prism through which to think about this war - yet Hilda Kean's scholarly book does exactly this. It seeks to fulfill the aim of those who work in the field of Animal Studies to place animals center stage in the historical narratives. But how much lasting this significance this will have in terms of historiography is open to question, given the limited success of those with similar aims in women's history, black history and LGBT History. Kean does however demonstrate that once attitudes and behaviour towards pet animals are added into the mix, familiar historical narratives of the conflict are unpicked, dislodged, undermined or at the very least shown in a very different light. Thus Kean's research offers scope for a rethinking of a number of historical approaches to the Second World War.

In reminding historians that during the Second World War, 'animals and humans shared the same space and events' (p. 18), Kean calls for a re-imagining of life in the home on the home front. She reminds us that many domestic spaces were inhabited by, and contained, not just multiple relationships between humans, but relationships between humans and animals. In doing this, the text makes a contribution to the growing field of emotional history. It offers numerous examples of how the minutiae of people's emotional experience of 
wartime were shaped by or involved their pets. Examples range from the calming presence of Churchill's cat, often observed sleeping peacefully on his bed, to the pet owners found dead amongst the rubble after bombing raids with their arms firmly clasped around their beloved animal who died with them. A quote from Nella Last, the housewife whose writing about her everyday life in Barrow-on-Furness for Mass Observation Archives has become emblematic of the Home Front, demonstrates the emotional support people gained from their pets. Nella observes:

To me he is more than an animal; he has kindness, understanding and intelligence and not only knows all that is said but often reads my mind to an uncanny degree. He know when I am sad and dim and lies with his head on my foot, or follows me closely as if to day, "I cannot help you, but please understand you and will stand by".

As Kean argues there is often a sense in Nella Last's diaries that she got more support from her dog than her husband, and demonstrates that individuals, households and families facing the strains of fractured relationships, and living with the horrors and uncertainty of war, could be sustained by emotional relationships with animals.

It is appropriate that, given the contemporary cultural significance of the People's War to the national narratives of Britishness that both the opening and closing chapters of this book encourage the reader to think about the silences and selectivity of histories. Kean points to the complex inter-related issues of: cultural memory, popular narratives of the past, commemoration and national identity. As Kean argues the destruction of so many pet animals in 1939 does not sit comfortably with national narratives of Britishness; little wonder then that it has been forgotten. Furthermore, in wartime it is suggested constructions of Britishness were predicated upon a perception not only of Germans as the 'other' but as an uncivilized, uncaring 'other' in which the treatment of animals was used to define national identity. This was epitomized in the British press, according to Kean, which reported contrasting scenarios of ambassador's dogs. In 1939 the British Ambassador to returned home from Germany carrying Hippy, a Daschsbracke in his arms as he disembarked from the plane. This dog was apparently reported to be a dachshund, to demonstrate that the 'mature' British people were no longer subject to the 'hysteria and animosity towards the small dogs, vilified as German [that occurred] during the 1914-18 war' (p. 7). By contrast the German Ambassador to Britain, Ribbentrop, was described as heartlessly abandoning his Chow Baerchen, when he scuttled back to his own country at the outbreak of hostilities. The numerous British people who offered to give Baerchen a home, served to place emphasis the warm heartedness of the British. Less press attention it is pointed out was given to the outcomes of these scenarios; Baerchen's fate was a happy one compared to Hippy's who died shortly after completely a miserable six months in quarantine kennels.

In chapter two Kean charts social, cultural and political attitudes towards pets in Britain in the 1920s and 1930s and suggests the low status of companion animals set the scene that led to the killing of so many animals in September 1939. During the First World War the value of companion dogs was questioned. Working dogs such as sheep dogs, who often lived in the country and fulfilled a valuable economic function, were tolerated. But domestic pets were often perceived to be consuming scarce resources in a time of food shortage. There were charities set up to ensure that fighting men's dogs were fed and cared for during the conflict, as the dog by the fire was a significant symbol of the home that they were fighting for. But as Kean points out there were also suggestions for how pet guinea pigs might be cooked in a stew with mushrooms. Dog biscuits were not rationed during this conflict but their content was restricted and the 'sleek and groomed ... fat cats' at the Lambeth Cat Show received harsh criticism.

In the inter-war years cats, which were given houseroom in return for the task they performed in keeping down vermin, were viewed more sympathetically. Whilst such feline companions fended for themselves, dogs were predominantly fed on scraps. Animals' diet, their treatment and their veterinary care were shaped by the economic circumstances of the owners, and death and destruction of pets was far more common than in contemporary culture - unplanned and unwanted puppies and kittens were routinely drowned, distemper 
randomly shortened the lives of dogs, and chaining dogs outside houses was not uncommon, yet many relished the companionship provided by the dogs, cats and birds who shared their homes. Nevertheless civil servants had not made any clear preparations for animals' welfare in the event of total war and memories of the First World War helped seal the fate of many pets.

Chapter three charts the very varied responses people had towards the plight of animals in the first days of war, which saw the population in frantic activity. People returned library books and evacuated families, with unaccompanied children and the elderly or ill being sent to the countryside or even to other countries. Many shut up their houses and either sought new homes for their rabbits, birds, cats and dogs, or had them destroyed. There were huge queues outside animal shelters and vets. Wrongly, bombing was expected to begin immediately, with the first air raid warning taking place on the 3rd of September; while it did not produce the expected mass hysteria it did bring the dangers of modern industrial warfare into the lives and homes of the civilian population.

The mass destruction of animals that occurred in these early days of the conflict was not done with advice, support or guidance from the government; it was a personal response by many pet owners who were leaving their homes, uncomfortable about the luxury of keeping pets in wartime and worried about how they would feed their animals or how their pets would cope with bombing. The predicaments owners faced had a precedent in the Munich crisis of 1938, when numerous people had sought to have their animals destroyed but were generally persuaded to wait and see how events unfolded. Kean amply demonstrates that in 1939 there were other options for owners beyond destroying their pets. Some gave them away; whilst the Duchess of Hamilton established an evacuation scheme for dogs, which enabled many four legged friends to spend the duration of the conflict safe in a sanctuary created at her estate in Ferne, Wiltshire. As some people killed or gave up their pets to shelters or friends, others became pet owners for the first time. A young boy in London insisted his mother rescue a beautiful ginger cat he saw waiting in a queue for the local vet to be destroyed. The cat lived with them through the blitz. A wise decision perhaps, as the destruction of so many cats enabled vermin to breed unchecked in many areas of London with all the resultant problems.

Chapter four scrutinizes the first months of war, commonly referred to as the phony war. Bombs did not drop, the British Expeditionary Force made a fairly poor show of trying to defend France from the advancing German army and in June 1940, they were evacuated from the beaches at Dunkirk, an event that this book demonstrates has been very selectively incorporated into British cultural memory of the Second World War. The heroic story stoic little people enacting the retreat from France is, Kean argues, disrupted by placing into the narrative the fate of numerous stray dogs that had accompanied British soldiers as they fled across France heading for the Channel. Many men expected these dogs to be evacuated to Britain with them; some indeed were, but others were shot in Dunkirk by the military before the men departed and a significant number were killed by RSPCA inspectors after being placed in quarantine pens on their arrival in Britain.

Kean does not just point to the fragility of the relationship between companion animals and their owners, which led to the 1939 September massacre. The complex, contradictory and infinitely varied research that has been undertaken uncovers evidence of tenacious, new or repaired relationships between animals and their owners in the months that followed. There are examples of women who with their husband in the forces and their children evacuated acquired dogs for company, or of evacuee children being cheered by letters from home containing the paw print of their very much missed pet and of Mrs Hill in Devon who gave houseroom to both a London child evacuee and a Samoyed dog who provided one another with tremendous comfort.

The uncertain luxury status of pets consuming scarce food resources in terms of wartime is the focus of chapter five. It is easy to forget that a wide range of foods were not rationed in wartime and so could be consumed by those with the financial resources to buy them, or indeed by their pets. What an exploration of the feeding of animals in wartime underlines is how many decisions about rationing were not made for purely pragmatic reasons; rationing was also about morale. Hence there was no genuine attempt to feed the population worms, although they had the potential to produce a phenomenal yield of protein per acre, but the 
population was guaranteed a ration of tea a week. The government committed itself to import tea across oceans where submarine warfare was raging, although it had no nutritional value, as depriving the population of tea would be bad for morale. Kean draws attention to the calculations of the Ministry of Agriculture and Food that dogs were consuming 280,000 tons of food and cats 18,000,000 gallons of milk each year - even though giving cats milk-contravened government regulations. Ample evidence is provided of the population's remarkable commitment to feeding their animals and the ambivalent attitude of the authorities towards this because of the importance of pets for morale. It is suggested that the government decided against banning the production of animal food as it was thought likely this would lead to owners diverting more human food in the direction of pets. Kean argues that human and dog foods were becoming increasingly interchangeable. Housewives anxiously trying to feed their families often requisitioned bones and other 'waste' products provided for dogs to make stews and soups.

In the latter chapters of this book Kean provides a multiplicity of examples to support a convincing argument that after the 1939 massacre the relationship between humans and domestic animals was not only repaired but strengthened in wartime. People and their pets become increasingly mutually dependent on one another, supporting each other through the blitz, often sharing Anderson shelters in the garden. Strictly speaking communal shelters were not supposed to admit animals; some tied their dogs outside when they went into the shelter, but occasionally animals do seem to have been smuggled in and at least one London Square considered building an animal shelter. In a time of crisis the mutual support, to death and beyond, that animals and humans were able to provide each other with become crucial. Individuals like Nella Last, who had initially wondered if she should have her dog put down, came to rely upon them. For those who do not 'get' Animal Studies, or for how many people a pet is part of their family, these chapters may be harder going. There may be some who will criticise this book for over-emphasizing the experience of Londoners. But for all those interested in the Second World War British Home Front, national narratives of the past, constructions of nationhood or emotional history this is an important book, and a welcome contribution to the ongoing process of chipping away at the pernicious national narrative of the Second World War as a 'People's War'.

\section{Other reviews:}

LA Review of Books

https://lareviewofbooks.org/article/the-pets-war-on-hilda-keans-the-great-cat-and-dog-massacre/ [2]

New York Times

https://www.nytimes.com/2017/04/21/books/review/great-cat-and-dog-massacre-hilda-kean.html [3]

Wall Street Journal

https://www.wsj.com/articles/londons-dogs-go-to-heaven-1490914219 [4]

Source URL:https://reviews.history.ac.uk/review/2184

\section{Links}

[1] https://reviews.history.ac.uk/item/277549 [2] https://lareviewofbooks.org/article/the-pets-war-on-hildakeans-the-great-cat-and-dog-massacre/ [3] https://www.nytimes.com/2017/04/21/books/review/great-cat-anddog-massacre-hilda-kean.html [4] https://www.wsj.com/articles/londons-dogs-go-to-heaven-1490914219 